Full-text Available Online at www.ajol.info and www.bioline.org.br/ja
J. Appl. Sci. Environ. Manage. Dec., 2015

Vol. 19 (4) 706 - 716

\title{
Distribution of different fractions of Iron, Zinc, Chromium, lead and Nickel in Soils around Petrol filling stations in selected Areas of Delta State, Nigeria
}

\section{*11OSAKWE, STEPHEN ANAPUWA; ${ }^{2}$ OKOLIE, LUCKY PRECIOUS}

\author{
Department of Chemistry, Delta State University, Abraka, Nigeria
}

*Correspondence Authore-mail: saosakwe@gmail.com

\begin{abstract}
The geochemical forms of some heavy metals in soils around selected petrol filling stations were studied in order to assess the mobility and bioavailability of the metals and hence their potential environmental risk. Water soluble fraction $\left(\mathrm{F}_{1}\right)$ contained an average of $0.97 \%$ iron, $1.40 \%$ zinc, $2.37 \%$ chromium, $2.08 \%$ lead and $41.96 \%$ nickel with the abundance trend of $\mathrm{Ni}>\mathrm{Cr}>\mathrm{Pb}>\mathrm{Zn}>\mathrm{Fe}$. Metal bound to exchangeable phase followed the same abundance trend with an average of $6.46 \%$ nickel, $5.48 \%$ chromium, $2.64 \%$ lead, $2.55 \%$ zinc and $0.62 \%$ iron. Lead was predominantly associated with carbonate fraction with an average of $52.32 \%$ followed by iron with an average of $15.41 \%$. Other metal average levels in the carbonate fractions were $9.66 \%$ for nickel, $8.78 \%$ for chromium, and $8.73 \%$ for zinc giving the abundance trend of $\mathrm{Pb}>\mathrm{Fe}>\mathrm{Ni}>\mathrm{Cr}>\mathrm{Zn}$. The most important metal in iron-manganese oxide phase was zinc with an average of $42.49 \%$, followed by iron with an average of $32.82 \%$. The averages of the other metals bound to this phase were $30.39 \%, 13.24 \%$ and $6.46 \%$ for chromium, lead and nickel respectively. The organic bound metals were in the abundance trend of $\mathrm{Fe}>\mathrm{Zn}>\mathrm{Cr}>\mathrm{Pb}>\mathrm{Ni}$ with average of $39.48 \%$ for iron, $30.87 \%$ for zinc, $23.03 \%$ for chromium, $8.54 \%$ for lead and $4.94 \%$ for nickel. Nickel with an average of $51.58 \%$ was predominantly associated with the residual fraction. The other metals bound to this phase in order of their importance to the fraction had the average of $22.75 \%$ for chromium, $13.96 \%$ for zinc, $12.24 \%$ for lead and $10.97 \%$ for iron. The mobility factor values of the metals were moderately high with the abundance trend of $\mathrm{Pb}>\mathrm{Ni}>\mathrm{Cr}>\mathrm{Fe}>\mathrm{Zn}$. The generally low levels of the metals in the residual fraction coupled with the mobility factor trend suggest potential risk for the metals. CJASEM
\end{abstract}

http://dx.doi.org/10.4314/jasem.v19i4.19

KEYWORDS: Soil pollution, speciation, petrol filling stations, heavy metals, Delta State.

\section{INTRODUCTION}

Total concentrations of metals in soils are a poor indicator of metal toxicity since metals exist in different solid-phase forms that can vary greatly in terms of their bioavailability (Krishnamurti et al, 1995; Krishnamurti and Naidu; 2002; Huang and Gobran, 2005; Violante et al., 2010). Therefore the determination of total soil metal content alone is not a good measure of bioavailability and not a very useful tool to quantify contamination and potential environmental and human health risk (Violante et al., 2010). The biological uptake and their ecotoxicological effects on the soil biota can be better understood in terms of their chemical speciation (Violante et al., 2010).

The speciation of heavy metals exerts strong influences on the mobility, bioavailability and toxicity of heavy metals in contaminated soils (Ure and Davidson., 2013). Among other techniques available to estimate the geochemical partitioning of heavy metals in soils, sequential extraction procedure has been widely accepted (Bacon and Davidson, 2008), and it is widely recognized as a useful tool for determination of different chemical or binding forms of heavy metal with sediments (Tessier et al., 1979, Das et al., 2015).

Several sequential extraction schemes have been employed to assess various species of metals in soils and reveal different forms of heavy metals and their level of bioavailability in soils and sediments. Some of the schemes include those employed by McLaren and Crawford, (1973); Tessier et al., (1979); Chao, (1984); Clavenger, (1990) and others. Among all these, the procedure adapted by Tessier et al., (1979) is generally accepted as the most commonly used protocol followed closely by the BCR (Shan and Chen, 1994; Tu et al., 1994; Zimmerman and Wendorf, 2010).

The overall objective of this study is to determine the geochemical forms of the selected heavy metals in the contaminated soils in order to assess their 
mobility and availability to biota. This will facilitate the quantification of the contamination and potential environmental human risk.

\section{MATERIALS AND METHODS}

Study Area: Abraka, a university town located in Ethiope East Local Government area of Delta State, lies approximately on latitude $5^{0} 48^{1} \mathrm{~N}$ and longitude $6^{0} 06^{1} \mathrm{E}$. The presence of the university leads to high population and a lot of commercial activities.

Agbor, the administrative headquarters of Ika South Local Government Area, located in the Northern part of Delta State, lies within the co-ordinates of latitude $6^{0} 05^{1} \mathrm{~N}$ to $6^{0} 16^{1} \mathrm{~N}$ and longitude $6^{0} 07^{1} \mathrm{E}$ to $6^{0} 12^{1} \mathrm{E}$. In addition to the presence of tertiary institution, the city experiences an average industrialization like foam, and paint manufacturing industries, commercial activities and transportation.

Asaba, the administrative headquarters of Oshimili South Local Government Area is also the administrative capital of Delta State. It lies within the coordinates of latitude $6^{0} 02 \mathrm{E}$ and longitude $6^{0} 23 \mathrm{~N}$. In addition to administrative activities, a lot of commercial activities also take place in the city.

Ughelli is the administrative headquarters of Ughelli North Local Government Area of Delta State. It lies within the coordinates of latitude $5^{0} 30^{1} \mathrm{~N}$ and longitude $5^{0} 59^{1}$ E. Petroleum extraction by Shell Oil company takes place in this city and it is a famous producer of glass bottles and other glass products and also a commercial centre.

Warri, a highly industrialized and the biggest oil city in Delta State lies within the coordinates of latitude
$5^{0} 30^{1} \mathrm{~N}$ and longitude $5^{0} 29^{1} \mathrm{E}$. Some of the industries include refinery, Shell Petrochemical Development Company (SPDC), and those rendering services to oil and gas sectors. These attract a large population and many commercial activities. The city also has three tertiary institutions which are Federal University of Petroleum Resources, Petroleum Training Institute and College of Education.

Sample Collection: Soil samples were collected from soils in the vicinity of petrol filling stations from five cities in Delta State of Nigeria namely Abraka, Agbor, Asaba, Ughelli and Warri. The soils were collected at depths of $0-15 \mathrm{~cm}, 15-30 \mathrm{~cm}$ and $30-45 \mathrm{~cm}$ representing top, sub and bottom soils respectively. In each city, four busy petrol filling stations were selected for the sampling and the samples collected from each depth in the four stations from the city were bulked and mixed thoroughly to form a composite sample using the method of coning and quatering (Ayodele and Gaya, 1998). Control samples were also collected from a site far remote from the effect of any industrialization or transportation activity.

Sample Preparation: The samples were air-dried, ground, and filtered through a $2 \mathrm{~mm}$ stainless steel sieve. They were then oven-dried at $105 \pm 0.5^{\circ} \mathrm{C}$ to a constant mass, cooled and stored until analysis (Allen et al., 1974).

Sample Analysis: The chemical speciation of the metals was carried out using the method of Lo and Yang as modified by Asagba et al., (2007). 1g of the soil samples was weighed and extracted into six fractions as shown in Table 1 below;

Table 1: Sequential extraction procedure for the speciation of the heavy metals

\begin{tabular}{|c|c|c|c|c|}
\hline Step & Fractions & $\begin{array}{l}\text { Extraction reagent/procedure } \\
\text { (Per 1g dry sample in a centrifuge) }\end{array}$ & $\begin{array}{l}\text { Shaking time and } \\
\text { temperature }\end{array}$ & \\
\hline 1 & $F_{1}$ Water soluble & $10 \mathrm{ml}$ of deionized water & 16hours & \\
\hline 2 & $\mathrm{~F}_{2}$ Exchangeable & $10 \mathrm{ml}$ of $1 \mathrm{M} \mathrm{MgCl}_{2}$ & 10hours & \\
\hline 3 & $\mathrm{~F}_{3}$ Carbonate & $8 \mathrm{ml}$ of $\mathrm{IM} \mathrm{NaOAc}$ adjusted to $\mathrm{P}^{\mathrm{H}} 5$ with $\mathrm{HOAC}$ & 5hours & \\
\hline 4 & $\mathrm{~F}_{4}+\mathrm{Fe}-\mathrm{Mn}$ Oxide & $20 \mathrm{ml}$ of $0.04 \mathrm{NH}_{2} \mathrm{OH} . \mathrm{HCl}$ in $25 \% \mathrm{HOA}_{\mathrm{C}}$ & $\begin{array}{l}\text { Occasional } \\
96 \pm 3^{0} \mathrm{C}\end{array}$ & 6hours, \\
\hline 5 & $\mathrm{~F}_{5}$ Organic & $\begin{array}{l}3 \mathrm{ml} \text { of } 0.02 \mathrm{M} \mathrm{HNO}_{3} \text { and } 5 \mathrm{ml} \text { of } 30 \% \mathrm{H}_{2} \mathrm{O}_{2}\left(\mathrm{P}^{\mathrm{H}} 2.0\right) \\
\text { Plus additional } 3 \mathrm{ml} \text { of } 30 \% \mathrm{H}_{2} \mathrm{O}_{2}\end{array}$ & $\begin{array}{l}\text { Occasional shaking } \\
85 \pm 2^{0} \mathrm{C} \\
85 \pm 2^{0} \mathrm{C} \text { 3hours }\end{array}$ & 2hours, \\
\hline 6 & $\mathrm{~F}_{6}$ Residual & $\begin{array}{l}5 \mathrm{ml} \mathrm{HF} \text { and } 10 \mathrm{ml} \mathrm{HCl0} 0_{4} \\
\left(\mathrm{HF}-\mathrm{HClO}_{4} \text { digestion) until the residue dissolved }\right.\end{array}$ & $\mathrm{HF}-\mathrm{HClO}_{4}$ digestion & \\
\hline
\end{tabular}

\section{RESULTS AND DISCUSSION}

The concentrations of the metals in various geochemical fractions of the soils are presented on Tables 2-6, while Table 7 presents the percentage metals in the fractions. 
Table 2: Concentrations $\left(\mathrm{mgkg}^{-1}\right)$ of iron (Fe) in various geochemical fractions of the soil

\begin{tabular}{llllllll}
\hline Sites & $\begin{array}{l}\text { Depth } \\
(\mathbf{c m})\end{array}$ & $\begin{array}{l}\text { Water } \\
\text { Soluble }\end{array}$ & Exchangeable & Carbonate & $\begin{array}{l}\text { Iron-manganese } \\
\text { Oxide }\end{array}$ & $\begin{array}{l}\text { Organic } \\
\text { matter }\end{array}$ & Residual \\
\hline \multirow{4}{*}{} & & $\mathbf{F}_{\mathbf{1}}$ & $\mathbf{F}_{\mathbf{2}}$ & $\mathbf{F}_{\mathbf{3}}$ & $\mathbf{F}_{\mathbf{4}}$ & $\mathbf{F}_{\mathbf{5}}$ & $\mathbf{F}_{\mathbf{6}}$ \\
& $0-15$ & 1.87 & 1.77 & 36.30 & 41.90 & 82.40 & 39.6 \\
& $15-30$ & 1.54 & 1.08 & 25.80 & 40.11 & 78.15 & 22.3 \\
$\mathbf{B}$ & $30-45$ & 1.31 & 0.84 & 19.60 & 26.30 & 37.46 & 7.9 \\
& $0-15$ & 2.31 & 1.33 & 48.20 & 45.83 & 33.86 & 39.1 \\
& $15-30$ & 1.85 & 1.31 & 40.60 & 42.14 & 28.82 & 21.9 \\
$\mathbf{C}$ & $30-45$ & 1.31 & 0.82 & 23.70 & 17.87 & 7.75 & 10.3 \\
& $0-15$ & 2.67 & 1.08 & 16.80 & 71.15 & 81.34 & 10.7 \\
& $15-30$ & 1.56 & 0.72 & 11.10 & 55.08 & 76.08 & 7.15 \\
$\mathbf{D}$ & $30-45$ & 0.77 & 0.63 & 7.80 & 18.39 & 70.88 & 4.26 \\
& $0-15$ & 1.77 & 1.26 & 23.40 & 70.08 & 63.81 & 5.84 \\
& $15-30$ & 1.31 & 1.05 & 21.00 & 58.54 & 59.35 & 4.41 \\
$\mathbf{E}$ & $30-45$ & 0.41 & 0.51 & 11.70 & 48.15 & 33.92 & 3.48 \\
& $0-15$ & 1.05 & 0.39 & 17.10 & 71.11 & 78.88 & 35.6 \\
& $15-30$ & 0.44 & 0.31 & 11.70 & 68.47 & 78.83 & 13.9 \\
& $30-45$ & 0.41 & 0.15 & 8.40 & 47.21 & 76.63 & 5.49 \\
\hline
\end{tabular}

\begin{tabular}{lll}
\multicolumn{2}{l}{ Key to sites } \\
A & - & Abraka \\
B & - & Agbor \\
C & - & Asaba \\
D & - & Ughelli \\
E & - & Warri
\end{tabular}

Table 3: Concentrations $\left(\mathrm{mgkg}^{-1}\right)$ of zinc $(\mathrm{Zn})$ in various geochemical fractions of the soil

\begin{tabular}{lllllllll}
\hline Sites & $\begin{array}{l}\text { Depth } \\
(\mathbf{c m})\end{array}$ & $\begin{array}{l}\text { Water } \\
\text { soluble }\end{array}$ & Exchangeable & Carbonate & $\begin{array}{l}\text { Iron-manganese } \\
\text { oxide }\end{array}$ & $\begin{array}{l}\text { Organic } \\
\text { Matter }\end{array}$ & $\begin{array}{l}\text { Residua } \\
\text { l }\end{array}$ & Total \\
\hline & & $\mathbf{F}_{\mathbf{1}}$ & $\mathbf{F}_{\mathbf{2}}$ & $\mathbf{F}_{\mathbf{3}}$ & $\mathbf{F}_{\mathbf{4}}$ & $\mathbf{F}_{\mathbf{5}}$ & $\mathbf{F}_{\mathbf{6}}$ & \\
$\mathrm{A}$ & $0-15$ & 0.94 & 2.51 & 7.20 & 59.67 & 26.07 & 6.91 & 103.3 \\
& $15-30$ & 0.79 & 0.94 & 6.90 & 36.09 & 16.91 & 5.34 & 66.97 \\
& $30-45$ & 0.47 & 0.86 & 2.10 & 19.71 & 12.06 & 4.08 & 39.28 \\
$\mathrm{~B}$ & $0-15$ & 0.87 & 1.73 & 9.30 & 50.62 & 19.71 & 10.5 & 92.73 \\
& $15-30$ & 0.79 & 1.25 & 4.90 & 23.22 & 18.72 & 9.11 & 57.99 \\
& $30-45$ & 0.53 & 0.63 & 2.80 & 13.95 & 13.83 & 6.28 & 38.02 \\
$\mathrm{C}$ & $0-15$ & 1.40 & 2.98 & 13.2 & 47.31 & 30.06 & 9.71 & 104.66 \\
& $15-30$ & 1.10 & 2.67 & 5.10 & 16.83 & 24.21 & 5.97 & 55.88 \\
& $30-45$ & 0.79 & 1.73 & 2.70 & 12.27 & 16.14 & 3.77 & 37.4 \\
$\mathrm{D}$ & $0-15$ & 0.84 & 1.26 & 3.60 & 23.19 & 19.11 & 6.28 & 54.28 \\
& $15-30$ & 0.71 & 1.10 & 3.00 & 17.26 & 14.61 & 5.65 & 42.33 \\
& $30-45$ & 0.47 & 0.79 & 2.10 & 9.81 & 11.40 & 4.72 & 29.29 \\
$\mathrm{E}$ & $0-15$ & 0.97 & 1.73 & 8.70 & 26.83 & 17.34 & 20.1 & 75.67 \\
& $15-30$ & 0.78 & 1.41 & 4.50 & 18.67 & 14.40 & 11.9 & 51.66 \\
& $30-45$ & 0.63 & 0.86 & 1.60 & 5.49 & 13.98 & 7.85 & 30.41 \\
\hline
\end{tabular}

Table 4: Concentrations $\left(\mathrm{mgkg}^{-1}\right)$ of Chromium $(\mathrm{Cr})$ in various geochemical fractions of the soil

\begin{tabular}{|c|c|c|c|c|c|c|c|c|}
\hline Sites & $\begin{array}{l}\text { Depth } \\
\text { (cm) }\end{array}$ & $\begin{array}{l}\text { Water } \\
\text { soluble }\end{array}$ & Exchangeable & Carbonate & $\begin{array}{l}\text { Iron-manganese } \\
\text { oxide }\end{array}$ & $\begin{array}{l}\text { Organic } \\
\text { matter }\end{array}$ & Residual & Total \\
\hline \multirow{4}{*}{ A } & & $F_{1}$ & $\mathbf{F}_{2}$ & $\mathbf{F}_{3}$ & $\mathbf{F}_{4}$ & $F_{5}$ & $F_{6}$ & \\
\hline & $0-15$ & 0.36 & 0.82 & 1.80 & 4.33 & 2.86 & 3.45 & 13.62 \\
\hline & $15-30$ & 0.29 & 0.68 & 1.40 & 2.76 & 1.82 & 2.40 & 9.35 \\
\hline & $30-45$ & 0.22 & 0.60 & 0.60 & 2.23 & 1.20 & 2.01 & 6.86 \\
\hline \multirow[t]{3}{*}{ B } & $0-15$ & 0.67 & 0.74 & 1.50 & 6.81 & 3.92 & 4.79 & 18.43 \\
\hline & $15-30$ & 0.61 & 0.65 & 1.20 & 4.29 & 3.16 & 2.97 & 12.88 \\
\hline & $30-45$ & 0.52 & 0.60 & 0.70 & 2.13 & 2.63 & 1.44 & 8.02 \\
\hline \multirow[t]{3}{*}{$\mathrm{C}$} & $0-15$ & 0.45 & 0.71 & 1.40 & 12.5 & 6.74 & 6.24 & 28.04 \\
\hline & $15-30$ & 0.34 & 0.62 & 0.90 & 6.57 & 3.68 & 4.30 & 16.41 \\
\hline & $30-45$ & 0.25 & 0.59 & 0.50 & 4.05 & 2.45 & 3.60 & 11.44 \\
\hline \multirow[t]{3}{*}{$\mathrm{D}$} & $0-15$ & 0.26 & 0.84 & 1.80 & 7.89 & 4.82 & 3.30 & 18.46 \\
\hline & $15-30$ & 0.23 & 0.81 & 0.90 & 6.79 & 3.87 & 2.10 & 14.70 \\
\hline & $30-45$ & 0.15 & 0.79 & 0.70 & 5.28 & 2.55 & 1.71 & .18 \\
\hline \multirow[t]{3}{*}{ E } & $0-15$ & 0.17 & 0.91 & 1.50 & 6.45 & 3.85 & 3.80 & 16.68 \\
\hline & $15-30$ & 0.14 & 0.72 & 1.10 & 4.29 & 2.52 & 2.95 & 11.72 \\
\hline & $30-45$ & 0.06 & 0.63 & 0.90 & 2.64 & 1.58 & 1.30 & 7.11 \\
\hline
\end{tabular}


Table 5: Concentrations $\left(\mathrm{mgkg}^{-1}\right)$ of nickel (Ni) in various geochemical fractions of the soil

\begin{tabular}{lllllllll}
\hline Sites & $\begin{array}{l}\text { Depth } \\
(\mathbf{c m})\end{array}$ & $\begin{array}{l}\text { Water } \\
\text { soluble }\end{array}$ & Exchangeable & Carbonate & $\begin{array}{l}\text { Iron-manganese } \\
\text { oxide }\end{array}$ & $\begin{array}{l}\text { Organic } \\
\text { matter }\end{array}$ & Residual & Total \\
\hline & & $\mathbf{F}_{\mathbf{1}}$ & $\mathbf{F}_{\mathbf{2}}$ & $\mathbf{F}_{\mathbf{3}}$ & $\mathbf{F}_{\mathbf{4}}$ & $\mathbf{F}_{\mathbf{5}}$ & $\mathbf{F}_{\mathbf{6}}$ & \\
$\mathrm{A}$ & $0-15$ & 9.13 & 1.39 & 3.30 & 0.72 & 1.12 & 42.3 & 57.96 \\
& $15-30$ & 6.00 & 1.13 & 1.80 & 0.57 & 0.92 & 26.9 & 37.32 \\
& $30-45$ & 4.70 & 0.78 & 1.40 & 0.48 & 0.62 & 15.4 & 23.38 \\
$\mathrm{~B}$ & $0-15$ & 6.70 & 0.61 & 3.00 & 0.63 & 0.71 & 36.7 & 48.35 \\
& $15-30$ & 6.26 & 0.53 & 2.10 & 0.39 & 0.48 & 15.1 & 24.86 \\
& $30-45$ & 3.65 & 0.47 & 1.70 & 0.21 & 0.12 & 9.67 & 15.91 \\
$\mathrm{C}$ & $0-15$ & 6.70 & 1.47 & 2.10 & 0.57 & 1.45 & 4.97 & 17.26 \\
& $15-30$ & 5.39 & 0.96 & 1.80 & 0.42 & 0.82 & 2.71 & 12.10 \\
& $30-45$ & 3.34 & 0.61 & 1.10 & 0.33 & 0.49 & 1.54 & 7.41 \\
$\mathrm{D}$ & $0-15$ & 4.61 & 2.78 & 1.90 & 0.45 & 1.64 & 3.42 & 14.80 \\
& $15-30$ & 3.97 & 0.96 & 1.20 & 0.33 & 0.84 & 1.24 & 8.54 \\
$\mathrm{E}$ & $30-45$ & 2.61 & 0.72 & 1.10 & 0.27 & 0.52 & 0.89 & 6.11 \\
& $0-15$ & 3.83 & 1.49 & 2.40 & 0.36 & 1.21 & 30.8 & 40.09 \\
& $15-30$ & 3.31 & 1,21 & 2.10 & 0.24 & 0.92 & 23.0 & 29.54 \\
\hline
\end{tabular}

Table 6: Concentrations $\left(\mathrm{mgkg}^{-1}\right)$ of lead $(\mathrm{Pb})$ in various geochemical fractions of the soil

\begin{tabular}{|c|c|c|c|c|c|c|c|c|}
\hline Sites & $\begin{array}{l}\text { Depth } \\
\text { (cm) }\end{array}$ & $\begin{array}{l}\text { Water } \\
\text { soluble }\end{array}$ & Exchangeable & Carbonate & $\begin{array}{l}\text { Iron-manganese } \\
\text { oxide }\end{array}$ & $\begin{array}{l}\text { Organic } \\
\text { matter }\end{array}$ & Residual & Total \\
\hline \multirow[t]{2}{*}{ A } & $0-15$ & 0.40 & 0.35 & 6.60 & 2.54 & 1.46 & 1.89 & 13.24 \\
\hline & $30-45$ & 0.26 & 0.28 & 3.30 & 1.21 & 0.82 & 0.84 & 5.97 \\
\hline \multirow[t]{2}{*}{ B } & $0-15$ & 0.33 & 0.66 & 9.90 & 2.24 & 1.62 & 2.16 & 16.91 \\
\hline & $15-30$ & 0.31 & 0.57 & 6.60 & 1.89 & 1.46 & 1.83 & 12.66 \\
\hline \multirow[t]{3}{*}{$\mathrm{C}$} & $0-15$ & 0.24 & 0.64 & 11.4 & 2.13 & 1.42 & 1.88 & 17.71 \\
\hline & $15-30$ & 0.18 & 0.45 & 8.28 & 1.96 & 1.26 & 1.21 & 13.34 \\
\hline & $30-45$ & 0.88 & 0.28 & 5.32 & 1.40 & 0.94 & 0.87 & 9.69 \\
\hline \multirow[t]{3}{*}{$\mathrm{D}$} & $0-15$ & 0.15 & 0.17 & 10.8 & 1.33 & 0.82 & 1.98 & 15.25 \\
\hline & $15-30$ & 0.13 & 0.15 & 7.50 & 0.98 & 0.61 & 1.21 & 10.28 \\
\hline & $30-45$ & 0.07 & 0.12 & 4.20 & 0.82 & 0.53 & 0.98 & 6.72 \\
\hline
\end{tabular}

Water Soluble Fractions (Fi): The percentage of iron in this fraction ranged from 0.85 to $1.48 \%$ with an average of $0.97 \%$. Low amount of iron in this fraction has been reported by Iwegbue et al., (2009); Osakwe, (2013.). The relatively low amount of iron in this fraction could be attributed to the fact that iron is easily absorbed and utilized by plants and other organisms in the soil environment. Zinc content varied from 1.05 to $1.66 \%$ with an average of $1.40 \%$. A similar low level of Zinc associated with this fraction was reported by Ajibola and Ozigis, (2005). The amount of chromium ranged from 1.04 to $4.58 \%$ with an average value of $2.37 \%$. Low level of chromium was reported by Birch et al., (2001) in cox sediments. Lead content ranged from 0.57 to 3.29 with an average of $2.08 \%$. Asagba et al., (2007) reported a relatively low percentage of lead in this fraction. Nickel concentration ranging from 12.01 to $41.96 \%$ with an average of $25.46 \%$ is the most associated metal with this fraction among all the metals studied. The abundance trend of the metals in this fraction is $\mathrm{Ni}>\mathrm{Cr}>\mathrm{Pb}>\mathrm{Zn}>\mathrm{Fe}$.
Water soluble fraction consists of metal species found in soil solution as ions which occur either as free hydrated ions or as various complexes with organic or inorganic ligands (Sparks, 2003). The metals in this fraction have the highest mobility and are thus easily available to biota and can also be leached into both surface and underground water sources (Asagba et al., 2007). Since metals in this fraction are usually thought to be available for plant uptake (Xian, 1989), the high percentage of Nickel in this fraction suggests a greater contamination risk for Nickel.

Exchangeable Fraction $\left(F_{2}\right)$ : The concentrations of iron found in the Exchangeable fraction varied from 0.16 to $0.94 \%$ with an average value of $0.62 \%$. Low iron content in exchangeable fraction has been reported (Horsfall and Spiff, 2005). The amount of zinc found in this fraction vary from 1.91 to $3.73 \%$ with an average of $2.55 \%$. Similar result has been reported in some other related studies (Gupta and 
Chen, 1975; Pizzaro et al., 2003). Ajibola and Ozigis (2005) reported an average of $2.69 \%$ of zinc in this fraction. Chromium content varied from 3.44 to 6.38 with an average of $5.48 \%$. Low level of chromium associated with exchangeable fraction was similarly observed in cox sidement (Birch et al., 2001) and municipal solid waste dumps in Agbor (Osakwe and Egharevba, 2008). The low amount of chromium in this fraction could be attributed to formation of poorly soluble hydroxo complexes by $\mathrm{Cr}$ (III) or oxyanions such as $\mathrm{Cr}_{4}{ }^{2-}$ and $\mathrm{Cr}_{2} \mathrm{O}_{7}{ }^{2-}$ by $\mathrm{Cr}$ (IV) which are minimally absorbed to negatively charged soil particles (Serene, 2010). The amounts of lead associated with this phase, vary from 0.94 to 4.48 with an average of $2.64 \%$. The levels of lead obtained in this fraction are consistent with the reports of Sheppard and Thilbaut, (1992); Kabala and Singh, (2001); Iwegbue, (2011); Osakwe et al., (2012). The percentage of Nickel bound to this phase ranged from
1.81 to $15.14 \%$ with the average of $6.46 \%$. The percentage concentrations of the metals in this phase are in the trend of $\mathrm{Ni}>\mathrm{Cr}>\mathrm{Pb}>7 \mathrm{n}>\mathrm{Fe}$.

Exchangeable fraction involves weakly adsorbed metals retained on the solid surface by relatively weak electrostatic interaction, and can be released by ion-exchangeable processes. Remobilization of metals can occur in this fraction due to adsorptiondesorption reactions and lowering of $\mathrm{P}^{\mathrm{H}}$ (Narwal et al., 1999). Metals in this phase have very high mobility and lability and can become readily available to plants and hence to the other living organisms through food chain (Bubb and Lester, 1991). Consequently there is high contamination risk for Nickel which ranked the highest percentage concentration among the metals considered in this study

Table 7: Various geochemical fractions of the soil expresssed as percentage of the metals

\begin{tabular}{|c|c|c|c|c|c|c|}
\hline Metal Fractions & A & B & $\mathrm{C}$ & $\mathrm{D}$ & $\mathrm{E}$ & Average \\
\hline \multicolumn{7}{|l|}{$\mathrm{Fe}$} \\
\hline $\mathrm{F}_{1}$-Water soluble & 1.01 & 1.48 & 1.14 & 0.85 & 0.37 & 0.97 \\
\hline $\mathrm{F}_{2}$-Exchangeble & 0.79 & 0.94 & 0.55 & 0.69 & 0.16 & 0.62 \\
\hline $\mathrm{F}_{3}$-Carbonate & 17.52 & 30.49 & 8.15 & 13.68 & 7.21 & 15.41 \\
\hline $\mathrm{F}_{4}$-Iron manganese & 23.23 & 28.68 & 32.86 & 43.12 & 36.19 & 32.82 \\
\hline $\mathrm{F}_{5}$-Organic matter & 42.47 & 19.09 & 52.10 & 38.31 & 45.41 & 39.48 \\
\hline $\mathrm{F}_{6}$-Residual & 14.97 & 19.32 & 5.05 & 3.35 & 10.66 & 10.67 \\
\hline \multicolumn{7}{|l|}{$\mathrm{Zn}$} \\
\hline $\mathrm{F}_{1}$-Water soluble & 1.05 & 1.16 & 1.66 & 1.60 & 1.51 & 1.40 \\
\hline $\mathrm{F}_{2}$-Exchangeble & 2.06 & 1.91 & 3.73 & 2.50 & 2.54 & 2.55 \\
\hline $\mathrm{F}_{3}$-Carbonate & 7.73 & 9.01 & 10.61 & 6.91 & 9.38 & 8.73 \\
\hline $\mathrm{F}_{4}$-Iron manganese & 55.10 & 46.51 & 38.60 & 39.92 & 32.33 & 42.49 \\
\hline $\mathrm{F}_{5}$-Organic matter & 26.27 & 27.69 & 35.57 & 35.84 & 28.98 & 30.87 \\
\hline $\mathrm{F}_{6}$-Residual & 7.79 & 13.72 & 9.83 & 13.22 & 25.26 & 13.96 \\
\hline \multicolumn{7}{|l|}{$\mathrm{Cr}$} \\
\hline $\mathrm{F}_{1}$-Water soluble & 2.92 & 4.58 & 1.86 & 1.44 & 1.04 & 2.37 \\
\hline $\mathrm{F}_{2}$-Exchangeble & 7.04 & 5.06 & 3.44 & 5.50 & 6.36 & 5.48 \\
\hline $\mathrm{F}_{3}$-Carbonate & 12.74 & 8.64 & 5.01 & 7.67 & 9.86 & 8.78 \\
\hline $\mathrm{F}_{4}$-Iron manganese & 31.24 & 33.64 & 4.37 & 45.02 & 37.68 & 30.39 \\
\hline $\mathrm{F}_{5}$-Organic matter & 19.71 & 24.69 & 23.03 & 25.35 & 22.39 & 23.03 \\
\hline $\mathrm{F}_{6}$-Residual & 26.34 & 23.39 & 25.30 & 16.04 & 22.67 & 22.75 \\
\hline \multicolumn{7}{|l|}{$\mathrm{Ni}$} \\
\hline $\mathrm{F}_{1}$-Water soluble & 16.71 & 18.64 & 41.96 & 38.00 & 12.01 & 25.46 \\
\hline $\mathrm{F}_{2}$-Exchangeble & 2.78 & 1.81 & 8.27 & 15.14 & 4.29 & 6.46 \\
\hline $\mathrm{F}_{3}$-Carbonate & 5.48 & 7.63 & 13.60 & 14.26 & 7.31 & 9.66 \\
\hline $\mathrm{F}_{4}$-Iron manganese & 1.49 & 1.38 & 3.59 & 3.57 & 0.88 & 2.18 \\
\hline $\mathrm{F}_{5}$-Organic matter & 2.24 & 1.47 & 7.51 & 10.19 & 3.27 & 24.68 \\
\hline $\mathrm{F}_{6}$-Residual & 71.30 & 68.97 & 25.07 & 18.85 & 73.70 & 51.58 \\
\hline \multicolumn{7}{|l|}{$\mathrm{Pb}$} \\
\hline $\mathrm{F}_{1}$-Water soluble & 3.29 & 2.20 & 3.19 & 1.09 & 0.57 & 2.08 \\
\hline $\mathrm{F}_{2}$-Exchangeble & 3.16 & 4.48 & 3.36 & 1.36 & 0.94 & 2.68 \\
\hline $\mathrm{F}_{3}$-Carbonate & 49.85 & 5.33 & 61.36 & 69.77 & 74.04 & 52.32 \\
\hline $\mathrm{F}_{4}$-Iron manganese & 18.91 & 15.12 & 13.48 & 9.71 & 9.11 & 13.24 \\
\hline $\mathrm{F}_{5}$-Organic matter & 11.13 & 10.88 & 8.89 & 6.08 & 5.43 & 8.54 \\
\hline $\mathrm{F}_{6}$-Residual & 14.26 & 14.01 & 9.72 & 12.93 & 9.91 & 12.24 \\
\hline
\end{tabular}

Carbonate Fraction $\left(F_{3}\right)$ : The amount of iron associated with this phase ranged from 7.21 to 30.49 with an average of $15.41 \%$. The average percentage of iron obtained in this fraction is in close agreement with the results obtained by Abeh et al., (2007);
Osakwe, (2010). Low iron percentage concentration in this fraction has been reported (Zhang et al., 1998; Horsfall and Spiff, 2005). Zn concentrations bound to this phase ranged from 6.91 to $10.61 \%$ with an average of $8.73 \%$. Similar levels of zinc bound to this 
fraction have been reported (Kotoky et al., 2003, Osakwe et al., 2012). Chromium concentrations ranged from 5.01 to $12.74 \%$ with an average of $8.78 \%$. Similar low concentration of chromium in this phase has been reported (Iwegbue, 2007). Significantly high level of lead ranging from 5.33 to $74.04 \%$ with an average of $52.32 \%$ was carbonate bound. Das et al., (2015) reported a substantial amount of lead bound to this phase. However a high level of lead associated with carbonate in this study is in contrast with the findings of some other researchers (Horfall and Spiff, 2005, Osakwe et al., 2012). Carbonate can be important absorbent for lead when organic matter and Fe-Mn oxides are less abundant in the ecosystem (Li et al., 2000; Das et al., 2015). The dominance of lead may be attributed to the formation of stable surface complexes (LopezSanchez et al., 1996; Jane and Turkie, 1997). Next of importance in this phase, was Nickel with concentrations ranging from 5.48 to $14.26 \%$ and an average of $9.66 \%$. This result is in very close agreement with those reported by Horsfall and Spiff, (2005); Osakwe, (2010); Osakwe, (2013). Low levels of Nickel associated with carbonate were reported by Tessier et al., (1979); Kotoky and Kittrick, (1984). The levels of metals bound to this phase are in the order of $\mathrm{Pb}>\mathrm{Fe}>\mathrm{Ni}>\mathrm{Cr}>\mathrm{Zn}$. Das et al., (2015) also reported highest percentage of lead in the carbonate fraction among the four metals studied.

The carbonate fraction is loosely bound and prone to changes with soil characteristics such as $\mathrm{P}^{\mathrm{H}}$ and redox conditions of the soil (Beck et al., 2001). Carbonates immobilize most heavy metals by providing an adsorbing or nucleating surface and by buffering the soil $\mathrm{P}^{\mathrm{H}}$ (Dudley et al., 1991). Since the metals bound to this phase may dissolve readily with alteration in environmental factors, the metals in this fraction are potentially available for uptake and release unto the environment leading to serious environmental risk.

Iron-Manganese oxide $\left(F_{4}\right)$ : Iron content in Fe-Mn oxide fraction varied from 23.23 to $43.12 \%$ with an average of $32.82 \%$. The substantial amount of iron in this phase could be attributed to transformation of $\mathrm{Fe}^{2+}$ into $\mathrm{Fe}^{3+}$ which is easily precipitated as $\mathrm{Fe}$ oxyhydroxide under strong oxidizing conditions and neutral $\mathrm{P}^{\mathrm{H}}$ values (Stumm and Morgan, 1981). This phase contained zinc varying from 32.33 to $55.10 \%$ with an average of $42.49 \%$. Similar percentage of zinc in this fraction has been reported (Harrison et al., 1981; Kuo et al., 1983; Hickey and Kittrick, 1984; Ramos et al., 1994; Iwegbue, 2007). Chromium amount was in the range between 4.37 and 45.03 with an average of $30.39 \%$. Osakwe, (2013) reported an average of $7.71 \%$ chromium in this phase. Fe-Mn oxide bound lead ranged from 9.11 to $18.91 \%$ with an average of $13.24 \%$. Similar level of oxideoccluded fraction of lead has been reported (Ramos et al., 1994; Singh, 2001). Substantial amount of lead in Fe-Mn oxide phase has been attributed to sorption of lead to manganese and iron oxides (Morin et al., 1999; Kotoky et al., 2003; Ogundiran and Osibanjo, 2009). The abundance trend is in the order $\mathrm{Zn}>\mathrm{Fe}>$ $\mathrm{Cr}>\mathrm{Pb}>\mathrm{Ni}$.

Iron-manganese oxide phase is referred to as reservoir for heavy metals. These oxides scavenge and appear as coating on mineral surfaces or as fine descrete particles and it can occur as a combination of the precipitation, adsorption, surface complex formation and ion exchange (Okoro et al., 2012). However, heavy metals retained in their forms may be potential source of contamination since they could be released if there are changes in the redox status of the soil (Wassay et al., 2001, Asagba et al., 2009)

Organic Matter Fraction $\left(F_{5}\right)$ : The organic bound iron was in the range 19.09 and $52.10 \%$ with an average of $39.48 \%$. This fraction contained the highest amount of iron. Similar result has been reported (Tessier et al., 1979). Osakwe, (2010) reported an average percentage of $28.45 \%$ in soils around automobile dumpsites in northern parts of Niger Delta, South Central Nigeria. Zinc associated with this fraction ranged from 26.27 to $35.84 \%$ with an average of $30.87 \%$. Iwegbue (2007) reported a range of $12-16 \%$ while Osakwe, (2012) reported an average of $6.19 \%$ zinc in this phase. Chromium levels varied from 19.71 to $25.35 \%$ with an average of $23.03 \%$. A similar association was reported by Sheppard and Thibault (1992); Iwegbue, (2007); Osakwe, (2010). Teixera et al., (2010) had suggested that zinc forms complexes with organic matter although less specifically than copper. The amount of lead found in this fraction ranged from 5.43 to $11.13 \%$ with an average of $8.54 \%$. The affinity of lead to this phase has been reported by some researchers (Kabala Pendias and Pendias, 1992; Asagba et al., 2007; Serene, 2010). Complexation of trace elements by organic ligands affects their mobility especially in aquatic systems influencing their solubility and uptake by organisms. Nickel bound to organic matter varied from 1.47 to $10.19 \%$ with an average of $4.94 \%$. This is in close agreement with the average of $4.14 \%$ reported by Osakwe (2013). Low level of nickel in this fraction was also reported by Kotoky et al., (2003). The abundance trend of metals in this phase is in the order of $\mathrm{Fe}>\mathrm{Zn}$ $>\mathrm{Cr}>\mathrm{Pb}>\mathrm{Ni}$. 
The primary source through which metals get associated with the organic materials such as living organisms, detritus etc is by bioaccumulation or complexation process (Okoro et al., 2012). The metals bound to this fraction are assumed to stay in the soil for longer period but may be immobilized by decomposition process (Kenedy et al., 1997). The metal forms associated with organic matter could be considered potentially active or strongly bound, depending on the physical properties of the soil (Ahumadu et al., 2004, Jamali et al., 2007, Kabirineja et al., 2014). Tessier et al., (1979), suggested that under oxidizing conditions, in natural waters, organic matter can be degraded, leading to a release of soluble trace metals.

Residual Phase $\left(F_{6}\right)$ : The concentrations of iron associated with Residual fraction ranged from 3.35 to $14.96 \%$ with an average of $10.97 \%$. Other researchers reported relatively higher percentage of iron in this fraction (Gupta and Chem, 1975; Horsfall and Spiff, 2005; Abeh et al., 2007; Segarra et al., 2008; Osakwe, 2010). Zinc levels had an average of $13.96 \%$ ranging from 7.79 to $25.26 \%$. A similar association of zinc with the residual fraction has been reported (Ma and Rao, 1997; Horsfall and Spiff, 2005). He et al, (2013) reported a relatively high range (40.3-68.5\%) of zinc in this phase. Some other researchers found very high level of zinc in this fraction viz 75\% (Bodog et al., 1996); 89\% (Querol et al., 1996). Residual phase bound chromium was in the range of 16.04 and $20.75 \%$ with an average of $22.75 \%$. This is consistent with various studies (Tukura et al., 2007; Segerral et al., 2008; Iwegbue et al., 2009). Ogundiran and Osibanjo reported predominance of chromium in non-residual fractions. Lead ranged from 9.72 to $14.265 \%$ with an average of $12.24 \%$. Many studies reported predominance of lead in this fraction (Chaudhary and Banerjee, 2007; Asagba et al., 2007; Osakwe and Egharevba, 2008; Osakwe et al., 2012). The levels of Nickel ranged from 18.85 to $73.70 \%$ with an average of $51.58 \%$. This predominance of inactive forms of nickel is in agreement with other studies of contaminated soils (Gupta and Chen 1975; Tessier and Campbell, 1980; Ma and Rao, 1997; Abeh et al., 2007; Chaudhary and Banerjee, 2007; Osakwe, 2010). Norrish, (1975) observed that nickel is commonly occluded by silicate during soil weathering. The levels of these metals are in the abundance trend of $\mathrm{Ni}>\mathrm{Cr}>\mathrm{Zn}>$ $\mathrm{Pb}>\mathrm{Fe}$.

The residual fraction is occluded with the crystal lattice layer of silicates and well crystallized oxide minerals and as such considered as the most stable, less reactive and less bioavailable (Terus, 1995; Abeh et al., 2007). The metals found in this phase are not expected to be released in solution over a reasonable time span under the conditions normally encountered in nature (Tessier et al., 1979). It serves as a very useful guide in the evaluation of long-term potential risk of heavy metal in the environment (Okoro et al., 2012). The smaller the percentage of the metal found in this fraction, the greater the pollution of the area, therefore iron and lead may pose the greatest potential environmental risk in this study.

The overwhelming importance of residual fraction clearly revealed by the results of many speciation studies illustrates clearly the difficulty of distinguishing between background and anomalous levels of trace metal contamination when the analysis of the metal levels is restricted to only determination of total metals (Tessier et al., 1979).

Mobility Factor: The early fractions, water soluble, exchangeable and carbonate $\left(\mathrm{F}_{1}+\mathrm{F}_{2}+\mathrm{F}_{3}\right)$ are regarded as the most reactive, most mobile and most potentially available/bioavailable fractions. The metals in these fractions consist of those that can be accessed by man through ingestion and are usually considered as being of anthropogenic origin (Asagba et al., 2007).

The metals in these phases are weakly or loosely bound to soil components and the relative index mobility of these metals was calculated as mobility factor (MF) (Salbu et al., 1998, Kabala and Singh, 2001) using the following equation.

$$
M F=\frac{F 1+F 2+F 3}{F 1+F 2+F 3+F 4+F 5+F 6} \times 100
$$

The mobility factors of the metals in the soil profiles are presented on Table 7 .

The range of mobility factors recorded in this study is higher than those reported by Iwegbue (2007); Osakwe and Eghareoba, (2008); Das et al., (2014). The values observed for Nickel increased with depth in all the sites which implies that the mobility and biological availability of Nickel increases with soil depth. However, there is no regular trend for the other metals. The mobility factors were observed to be in the trend: $\mathrm{Pb}>\mathrm{Ni}>\mathrm{Cr}>\mathrm{Fe}>\mathrm{Zn}$. Das et al., (2007) similarly reported highest mobility factor for lead among all the metals in their study. The relatively high mobility factors for lead and nickel may indicate potential risk by those metals in the environment. 
Table 8: Mobility Factors (MF) of the metals in the soil profiles

\begin{tabular}{lllllll}
\hline Sites & $\begin{array}{l}\text { Soil Depth } \\
\text { cm }\end{array}$ & Fe & Zn & $\mathbf{C r}$ & $\mathbf{N i}$ & $\mathbf{P b}$ \\
\hline $\mathbf{A}$ & $0-15$ & 19.59 & 10.31 & 21.88 & 23.84 & 55.51 \\
& $15-30$ & 16.82 & 12.89 & 25.35 & 23.93 & 56.71 \\
& $30-45$ & 23.28 & 8.73 & 20.70 & 29.43 & 57.23 \\
$\mathbf{B}$ & $0-15$ & 30.38 & 12.83 & 15.79 & 21.32 & 64.40 \\
& $15-30$ & 32.03 & 11.97 & 19.10 & 35.76 & 59.08 \\
& $30-45$ & 41.83 & 10.42 & 22.69 & 36.58 & 52.28 \\
$\mathbf{C}$ & $0-15$ & 11.18 & 16.80 & 9.13 & 59.50 & 69.34 \\
& $15-30$ & 8.82 & 15.87 & 11.33 & 67.36 & 66.79 \\
& $30-45$ & 8.96 & 13.96 & 11.71 & 68.15 & 66.87 \\
$\mathbf{D}$ & $0-15$ & 15.91 & 10.50 & 15.71 & 62.77 & 72.92 \\
& $15-30$ & 16.04 & 11.36 & 13.20 & 71.78 & 75.68 \\
& $30-45$ & 12.86 & 11.47 & 14.67 & 72.50 & 65.33 \\
$\mathbf{E}$ & $0-15$ & 9.08 & 15.07 & 15.47 & 18.13 & 78.70 \\
& $15-30$ & 7.17 & 12.95 & 16.72 & 22.41 & 76.29 \\
& $30-45$ & 6.48 & 10.16 & 22.36 & 37.49 & 62.15 \\
\hline
\end{tabular}

Conclusion: The speciation of the metals among the six geochemical phases revealed that $\mathrm{Fe}-\mathrm{Mn}$ oxide and organic phases proved to be of most importance for the soils examined in this study. This is because they contained significantly high amounts of iron, zinc and chromium. The predominant species of lead was associated with carbonate fraction while residual fraction contained majority of nickel.

The presence of low percentage of all the metals studied except nickel, in the residual fraction, is of great soil quality concern. Since the early fractions, which are water soluble, exchangeable and carbonate are the most mobile and most potentially available fractions and iron-manganese oxide occluded and organic bound metals can be released under favorable conditions, coupled with the relatively high mobility factor values, the soils under study may pose some potential environmental risk.

\section{REFERENCES}

Abeh, T., Gungshik, J. and Adamu, M.M. (2007). Speciation studies of trace element levels in sediments from Zaramagada stream in Jos, Plateau state . Nigeria. Journal of Chemical Society of Nigeria, 32(2): 218-225.

Ahumadu, I; Escudero, P., Castillo, G., Carrasco, A., Ascar, L. and Funtes, E. (2004). Use of sequential extraction to assess the influence of sewage sludge amendment on mental mobility in Chilean Soils. Journal of Environmental Monitoring, 6: 327-334.

Ajibola, V.O. and Ozigis, I. (2005). Partitioning of some heavy metals in Kaduna street soils. Journal of Chemical Society of Nigeria, 301(1):62-66.
Allen, S.E., Grinshaw, H.M., Parkinson, J.A. and Qjuarmby, C. (1974). Chemical methods for analyzing ecological materials. Oxford Blackwell Scientific Publications, London. 565.

Asagba, E.U., Okieimen, F.E. and Osokpor, J. (2007). Screening and speciation of heavy metal contaminated soil from automobile spare-parts market. Chemical Speciation and Bioavailability, 19 (1): 9-15.

Ayodele, T. and Gaya, U.M. (1998). Chromium, manganese and Zinc in Kano municipality street dust. Journal of Chemical Society of Nigeria. 23:24-31.

Bacon, J.R. and Davidson, C.M. (2008). Is there a future for sequential chemical extraction? Analyst, 133:25-46.

Beck, J.N., Gauthreaux, K. and Sneddon, J. (2001). Abstracts of papers, 221 $1^{\text {st }}$ ACS. National Meeting, San Diego, C.A. United States, April 15.

Birch, G., Saika, M and Owen, C. (2001). The source of anthropogenic heavy metals in fluvial sediments of a rural catchment, cox River, Australia Water, Air, and Soil Pollution, 126:1325 .

Bodog, I., Polyak, K., Csikos-Harlyanyi., Z. and Hlay, J. (1996). Sequential extracts on procedure for the speciation of elements in the fly ash samples. Microchemistry Journal, 54 (3): 320330 .

Bubb, J.M. and Lester, J.N. (1991). The impact of heavy metal on lowland rivers and the 
implication for man and the environment. Science of Total Environment, 100:207-233.

Chao, T.T. (1984). Use of partial dissolution techniques in geochemical exploration. Journal of Geochemical Exploration, 20:101-135.

Chaudhary, S. and Banerjee, D.K. (2007). Speciation of some heavy metals in coal fly ash. Chemical Speciation and Bioavailability, 19(3): 95-01.

Clevenger, T.E. (1990). Use of sequential extraction to evaluate the heavy metals in mining wastes, water, Air and Soil Pollution, 50: 241-255.

Das, P., Sarma, K.P. and Kumar, M. (2015). Understanding the chemical speciation of lead, zinc and copper in vertical profile of the sediments of the Brahmaputra River, Assam, India. Asian Journal of Water, Environment and Pollution, 12(1): 21-28.

Dudley, L.M., McLean, J.E., Furst, T.H. and Jurinak, J.J. (1991). Sorption of cadmium and copper from an acid mine waste extract by two calcareous soils: column study. Soil Science, 151: 121-135.

Gupta, S.K. and Chen, K.Y. (1975). Partitioning of trace metals in selected chemical fractions of nearshore sediments. Environmental Letters, 10:129-158.

Harrison, R..M., Laxen, D.P.H. and Wilson, S.J. (1981). Chemical association of lead, cadmium, copper and zinc in street dusts and roadside soils. Environmental Science and Technology, 15; 1378-1383.

Hass, A. and Fine, P. (2010). Sequential selective extraction procedures for the study of heavy metals in soils, sediments and waste materials A critical Review. Environmental Science and Technology, 40:365-399.

He, Q., Ren, Y., Mohammed, I., Ali, M., Hassan, W. and Zeng, F. (2013). Assessment of trace and heavy metal distribution by four sequential extraction procedures in a contaminated soil. Soil and Water research, 8(2): 71-76.

Hickey, M.C. and Kittrick, J.A. (1984). Chemical partitioning of cadmium, copper, nickel and zinc in soils and sediments containing high levels of heavy metals. Journal of Environmental Quality, 13:372-376.
Horsfall, M. (Jnr.) and Spiff, A. (2005). Speciation and bioavailability of heavy metals in sediments of Diobu River, Port Harcourt, Nigeria. European Journal of scientific Research, 6(3): 20-36.

Iwegbue, C.M.A. (2007). Metal fractionation in soil profiles at automobile mechanic waste dumps. Waste Management Research, 25: 1-9.

Iwegbue, C.M.A., Nwajei, G.E., Eguavoen, O. and Ogala, J.E. (2009). Fractionation of some heavy metals in soil profiles in vicinity of scrap dumps in Warri, Nigeria. Chemical Speciation and Bioavailability, 21(2): 99-110.

Iwegbue, C.M.A; (2011). Assessment of heavy metal speciation in soils impacted with crude oil in the Niger Delta, Nigeria. Chemical Speciation and Bioavailability 23(1) 9-15.

Jamali, M.M.; Kazi, T.G.; Arain, M.B., Afridi, H.I., Jalbani, N., Memon, A.R. and Shah, A. (2007). Heavy metal from soil and domestic sewage sludge and their transfer to sorghum plants. Environmental Chemistry sorghum plants. Environmental Chemistry Letters, 5: 209-218.

Jane, B. and Turkie, A. (1997). Distribution and speciation of heavy metals in surficial sediment from the Tees Estuary Northwest England. Marine Pollution Bulletin, 34; 768-779.

Kabala, C. and Singh, B.R. (2001). Fractionation and mobility of copper, lead and zinc in soil profile in the vicinity of a copper smelter. Journal of Environmental Quality, 30:485-495.

Kabala-Pendias, A. and Pendias, H. (1992). Trace elements in soil and plants. $2^{\text {nd }}$ Edn. CRC Press Baca Raton, F.L.

Kabirinejad, S., Kalbasi, M., Khoshgoftarmanesh, A.H., Hoodaji, M. and Afyuni, M. (2014). Chemical forms and phytoavailability of copper in soil as affected by crop residues incorporation. American Journal of Analytical Chemistry, 5:604-612.

Kennedy, H., Sanchez, A.L., Oughton, D.H., Rowland, A.P. (1997). Use of single and sequential chemical extractions to assess radionuctide and heavy metal availability from soils for root uptake. Analyst, 122: 89R-100R. 
Kotoky, P. Bora, B.J., Baruah, N.K., Baruah, J., Baruah, P. and Borah, G. O (2003). Chemical fractionation of heavy metals on soils around oil installations, Assam. Chemical Speciation and Bioavailability, 15(4) 115-126.

Krishnamurti, G.S.R. and Naidu, R. (2002). Solidsolution speciation and phytoavailability of copper and zinc in soils. Environmental Science and Technology, 36:2645-2651.

Krishnamurti, G.S.R., Huang, P.M., VanRees, K.C.J., Kozak, L.M and Rostad, H.P.W. (1995). Speciation of particulate-bound cadmium of soils and its bioavailability. The Analyst, 120:659665.

Li, B., Wang, Q, Huang, B., and Li, S (2001). Evaluation of the result from a Quasi-Tessier sequential extraction procedure for heavy metals speciation in soils and sediment by ICP-MS. Analytical Science, 17 (1):1561-1564.

Lo, I.M.C. and Yang, X.Y. (1998). Removal and redistribution of metals from contaminated soils by a sequential extraction method. Waste Management, 18:1-7.

Lopez-Sachez, J.F., Rubio, R., Samitier, C. and Rauret, G. (1996). Trace metal partitioning in marine sediment and sludge deposited off the coast of Barcelona, Spain Water Research, 3-, 153-159.

Ma, L.Q. and Rao, G.N. (1997). Chemical fractionation of cadmium, nickel and zinc in contaminated soils. Journal of Environmental Quality, 26:264.

McLaren, R.G. and Crawford, D.V. (1973). Studies on soil copper. 1: The fractions of copper in soils. Journal of Soil Science, 24:443-452.

Morin, G., Ostergren, J.D., Juliet, F., Ildefonse, P., Calas, O. and Gordon,. E.B. Jr. (1999). XAFS form of lead in smelter-contaminated soils and mine tailings. Importance of adsorption processes. American Mineral, 84: 420-434.

Narwal, R.P., Singh, B.R. and Saibu, B. (1999). Communications In Soil Science and Plant Analysis, 30:1209-1230.

Narwal, R.P., Singh, B.R. and Salbu, B. (1999). Sinc, copper and nickel with components in naturally heavy metal-rick soils studied by parallel and sequential extraction Communication in Soil Science and Plant Analysis, 30:1209-1230.

Ogundiran, M.B. and Osibanjo, O. (2009). Mobility and speciation of heavy metals in soils impacted by hazardous waste. Chemical Speciation and Bioavailability, 21(2):59-69.

Okoro, H.K., Fatoki, O.S., Adekola, F.A., Ximba, J. and Synman, R.G. (2012). A review of sequential extraction prodecures for heavy metal speciation in soil and sediments. Open Access Scientific Reports, 1(3):1-9.

Osakwe, S.A. (2010). Chemical speciation and mobility of some heavy metals in soils around automobile waste dumpsites in Northern part of Niger Delta, South Central Nigeria. Journal of Applied and Environmental Management, 14(4):123-130.

Osakwe, S.A. (2013). Chemical partitioning of Iron, Cadmium, Nickel and Chromium in contaminated soils of South-Eastern Nigeria. Chemical Speciation and Bioavailability, 25(1): 71-78.

Osakwe, S.A. and Egharevba, F. (2008). Sequential fractionation of cadmium, copper, lead and chromium in soils around municipal solid waste dumps in Agbor, Nigeria. Journal of Chemical Society of Nigeria, 33(2): 139-147.

Osakwe, S.A., Akpoveta, O.V. Okoh, B.E. and IzeIyamu, O.K. (2012). Chemical forms of heavy metals in soils around municipal waste dumpsites in Asaba metropolis, Delta State, Nigeria. Chemical Speciation and Bioavailability, 24:(1). 23-30.

Pizzaro, J., Rubio, M. and Castillo, X. (2003). Study of chemical speciation on sediments. An approach to vertical metal distribution in Rapel reservoir (Chile). Journal of Chile Chemical Society, 48:45-50.

Querol, X., Joan, R., Lopez-Soler, A., Fernandez Turiel, J.I. and Ruiz, C.R. (1996). Mobility of trace elements from coal and combustion wastes. Fuel, 75:821-838.

Ramos, L. Hernandez, L.M. and Gonzales, M. J. (1994). Sequential fractionation of copper, lead, cadmium and zinc in soils from Danana National Park. Journal of Environmental Quality, 25:5057. 
Ramos, L. Hernandez, L.M. and Gonzalez, M.J. (1994). Sequential fractionation of $\mathrm{Cu}, \mathrm{Pb}, \mathrm{Cd}$, and $\mathrm{Zn}$ in soils from or near Donana National park. Journal of Environmental Quality, 23:5057.

Segarra, M.J.B., Prego, R., Wilson, M.J., Bacon, J. and Santos-Echendia, J.S. (2008). Metal speciation in surface sediments of the Vigo Ria, N.W. Iberian Peninsula. Scientia Marine, 72(1) 119-136.

Serene, T. (2010). Mobility and transport of heavy metals in polluted soil environment. Biological forum- An international journal, 2(2): 112-121.

Sheppard, M.I. and Thibault, D.H. (1992).Desorption and extraction of selected heavy metals from soils. Soil Science Society of America Journal, 54: 415-423.

Sing, M.V. (2001). Evaluation of micronutrient stocks in different agroecological zones of India for sustainable crop production. Fertilizer News, Delhi, 46(2):25-42.

Sparks, D.L. (2003). Environmental Soil Chemistry, $3^{\text {rd }}$ Edition, Academic Press.

Stover, R.C., Sommers, L.E. and Silviera, D.Y. (1976). Evaluation of metals in waste water sludge. Journal of Water Pollution and Control Fed., 48:2165-2175.

Stumm, W. and Morgan, J.J. (1981). Aquatic chemistry; chemical equilibra and rates in natural water. John Willey and Sons Inc. USA. 1022.
Terus, A. (1995). Distribution of differential fractions of $\mathrm{Cd}, \mathrm{Zn}, \mathrm{Pb}$ and $\mathrm{Cu}$ in unpolluted and polluted soils. Water, Air and Soil pollution, 83: 1-4.

Tessier, A. and Campbell, P.G.C. (1980). Trace metal speciation in the Yamaska and St. Francis River (Quebed). Canadian Journal of Earth science, 17:99-105.

Tessier, A., Campbell, P. and Bisson, M. (1979) sequential extraction procedure for the speciation of particulate trace metals. Analytical chemistry, 51:844-851.

Ure, A.M. and Davison, C.M. (2002). Introduction in Ure, A.M. and Davison C.M. (eds). Chemical speciation in the Environment, $2^{\text {nd }}$ edition ed, C.M. Blackwell science, Oxford, 1-5.

Violante, A., Cozzolino, V., Perelomov, L., Caporale, A.G. and Pigna, M. (2010). Mobility and bioavailability of heavy metals and metalloids in soil environments. Journal of Soil Science and Plant Nutrition, 10(3): 268-292.

Wassay, S.A., Parker, W.J. and Van-Geel, P.J. (2001). Characterization of soil contaminated by disposal of battery industry waste. Canadian Journal of Civil Engineering, 28:341-348.

Xian, X. (1989). Effects of chemical forms of cadmium, zinc and lead in polluted soil on their uptake by cabbage plants. Plant and soil, 113: 257-264. 